\title{
Child-Friendly Through Hizbul Wathan in Indonesia Muhammadiyah School
}

\author{
$1^{\text {st }}$ Eni Fariyatul Fahyuni \\ Faculty of Islamic Studies \\ Universitas Muhammadiyah Sidoarjo \\ Indonesia \\ eni.fariyatul@umsida.ac.id
}

\author{
$2^{\text {nd }}$ Moch. Bahak Udin By Arifin \\ Faculty of Islamic Studies \\ Universitas Muhammadiyah Sidoarjo \\ Indonesia
}

\begin{abstract}
This article aims of child-friendly schools through Hizbul Wathan to learners are healthy, knowledgeable, noble character, and be a cadre of leaders. This is qualitative research used data on interviews, observation, and documentation of sources and methods triangulation. Concept of Hizbul Wathan based child-friendly emphasize the right of children to get quality education integrated with islamic values to change their ways of thinking and attitudes. Hizbul Wathan be able to build the character of growing responsibility, independence and honesty in daily activities. The child-friendly school through Hizbul Wathan integrated values al Islam and muhammadiyah to teach values, rules, norms in their lives.
\end{abstract}

Keywords-Child, Friendly, Hizbul Wathan, Muhammadiyah School

\section{INTRODUCTION}

The scouting movement in schools promoted in all provinces in Indonesia is still limited to getting a degree. This activity has not been able to develop the spirit of student leadership. In 1999, the Muhammadiyah Association examined the scouting movement called Hizbul Wathan (HW) based on several things, such as 1) the challenges of Muhammadiyah's current and future cadres; 2) including in Muhammadiyah schools through the HW movement; 3) the HW movement as a guide for Muhammadiyah cadre leaders, and 4) the era of democratic reform and moral enhancement [1]. The application of HW revitalizes scouting activities. the UK implements character education as an initial step of training and provides education and modeling for all teachers applying character education to students at all levels of the school [2]. Education has an essential role in human life. Education is not just a transformation of knowledge, but also the values of attitudes and morals to produce a generation who have characters [3] Based on religion. The role of vision and mission had been various programs act as a basis and direction for internalizing the learning process [4].

The HW movement aims to produce school leaders to prepare healthy, knowledgeable, high moral standards. It is ready to become broad-minded cadres and carry out the mission Amar ma'ruf, nahi munkar. However, the implementation of the HW in schools has not been optimal. The leadership applied is not entirely under the orientation towards achieving the expected goals. The use of technology as a learning medium has not been maximized to achieve the objectives [5]. The condition of the school challenges HW extracurricular activities based on values and aims to practice inclusive education [6]. The character of leadership needs to be early on. School success and student achievement are interrelated with instructional leaders to create a collaborative environment at school [7]. Leadership motivating others to follow directions and inspiring others to achieve common goals.

\section{DISCUSSION}

\section{A. Leadership Character School Leader}

The development of leadership characteristics based on values must be clarified before starting activities. The development of leadership character is related to one's awareness, self-concept, and motives in participating in this activity [8]. For this reason, leadership development programs must use a holistic approach. In this case, efforts designed in character development need to involve various parties to increase students' personal and interpersonal capacities [9]. The Organization for Economic Cooperation and Development (OECD) has declared that everyone has transformative competence, including 1) creating new values according to global challenges, 2) aligning various problems with appropriate solutions, 3) discipline and responsibility. These goals are closely related to the development of leadership character education for students [10].

Character building helps overcome various problems in the future. The results show that building leadership character must include teaching processes and capacity building skills, including improving the quality of teachers, classrooms, learning methods, and learning environments in schools. [11]. By instilling character, can form a strong foundation to prepare for the challenges and to change times [12]. Formation of character in Islamic education includes attitudes, traits, reactions, actions, and behavior. To form characteristics with Islamic values referring to the concept of character education, the application of character 
education cannot be separated from the values and guidelines of Islamic teachings. [13]. The subject matter that emphasizes character education in elementary schools can be done contextually by containing exemplary stories of the leadership of the prophets and heroes.

Character education is not limited to specific grade lavels. There are five keys to carrying out character education 1) planning for chacarter education; 2) implementing character education programs; 3) instilling educator character in a friendly manner and, most important, pay attention to children's right in learning, 4) giving supports program from various parties, principals, teachers, parent, and the community; 5) preparing students related to the newly implemented program so that students do not tend to be skeptical or apathetic toward the implementation of the new rules [14]

The results showed that leadership education applied to students hugely significantly improved two components at once. First, being able to reflect students' knowledge and experiences in a meaningful way so that they last a long time in their thinking. Second, being able to strengthen students' understanding and skills as a provision for living in a society [15]. For this reason, the role of teachers in schools in implementing character education is vital to form a strong foundation on which they will continue to grow and develop in society. [16]. It is important to create a child-friendly environment so that they can be treated with dignity, grow healthy, be active, enjoy the freedom to socialize with their peers [17]. Muhammadiyah's school emphazise from influence leadership. There are three leadership models applied, strategic leadership, transformational leadership, and leadership centered on learning. These three leadership models contribute to building the independence of Muhammadiyah schools [18].

A child-friendly learning environment stimulates student involvement in the learning process. It also helps develop students' cognitive abilities. Thus, the creation of a child-friendly learning environment requires teachers who are ready to: 1) train student self-control, 2) create collaborative learning atmosphere, 3 ) respect all ideas and ideas, 4) involve and provide support to all students during learning, and 5) become listener and facilitator in learning [19]. For this reason, the dynamics of interpersonal closeness between teacher and students play an important role in delivering the learning success of their students [20]. The results showed the role of teachers in implementing child-friendly school-based teaching is very dependent on the support of school stakeholders and their cooperation with parents and the community [21].

\section{B. Child-Friendly Islamic School}

The creation of child-friendly learning environment by providing the learning process that is under the rights and needs of students with the teacher accepting the difference more than having to force his will is the key to implementing student-friendly education [19]. For this reason, transparent and sustainable policies can optimize student learning potential. The problem of limited infrastructure is building collaboratively to be able to provide meaningful learning experiences for students [22]. The concept of child-friendly schools emphasizes the right of children to get quality education and can also help children learn according to what they need. [23]. Developing a child-friendly school is indeed a long process. Teachers, principals, parents, and the community need to collaborate in implementing child-friendly schools that are by the values they have agreed on [24] to improve the quality of education in schools [25] which is integrated with Islamic values to motivate students to change their ways of thinking and attitudes [26].

The HW scouting movement is to prepare Muhammadiyah cadres who are healthy, knowledgeable, and highly moral. The optimization attempt of HW extracurricular activities at school through four steps, such as planning, organizing, implementing, monitoring or evaluating, and following up. The results of this research are able to build the character of student leadership, (1) growing responsibility, independence, and honesty, (2) convincing and applying the material of HW activities in daily activities, and (3) increasing students' interest in finding Extracurricular Activities HW [27]. Similar research shows extracurricular activities in schools need to involve collaboration with parties [28], supported by the competence of professional educators [29], according to must be under mutually agreed values [21]. The character of leadership needs to be instilled early in school to encourage change for the better. Leadership means motivating others to follow directions and inspiring others to achieve common goals.

C. Leadership Character

Implementation of the HW scouting movement in Lab school Muhammadiyah 1 Primary School UMSIDA integration of Islamic values to realize child-friendly schools. Implementation of child-friendly schools requires proper management to teach values, rules, norms in their lives [30], which places student leadership in society [31]. The characteristics of child-friendly schools give priority to (1) aspects of the process, not the results; (2) refers to goals; (3) policy, supervision, and financing; (4) improve quality; (5) openness; and (6) discipline and responsibility (Hermino \& Luangsithedeth, 2017). Child-friendly schools must adapt to the needs, conditions, and context of the school [32].

The previous research shows that building religious values has a strong influence on the formation of the moral behavior of students. This finding illustrates that embed of ethical values through daily student experience can form good habits or characters for students (Yasina, Maizura; Abdullah, Nur Surayyah M; Roslan, S; Wahat, 2018). The 
conception of character education is by the content of pedagogy that not only emphasizes the results but in the process of character formation of students in schools [34], which integrated Islamic values into the learning process [35]. The HW movement that was given not only aimed at understanding students in the context of knowledge but made the values of the Qur'an and Sunnah as the basis and guidelines for students in living their lives in society. The leadership character constructs 1) be trusted; 2) loyal friends; 3) ready to help and obliged to be meritorious; 4) like peace and brotherhood; 5) have good manners and officers; 6) merciful to all beings; 7) carry out orders by not arguing; 8) patient and sweet-faced; 9) frugal and meticulous; and 10) sacred in thoughts, words, and deeds. The study findings show that the moral cultivation of religion in the family can shape a person's good behavior. Therefore the application of child-friendly schools through the HW movement integration of Islamic values is needed to instill character education based on the Qur'an and Sunnah.

\section{METHOD}

This type of research is a qualitative research that aims to identify various events or events related to the implementation of child-friendly schools in shaping the character of student leadership through the HW movement at school. Data collection techniques used interviews, observation, and documentation using triangulation of sources and methods [36]. Interviews with the school leadership, mentor HW, class teachers, students in grades 1 and 2, as well as student guardians at Lab school UMSIDA Muhammadiyah 1 Elementary School.

HW movement held every Thursday at 08.30 WIB 10.30 WIB. This research was conducted from the beginning of April 2019 until November 2019. There were several stages in implementing child-friendly schools through kepanduan HW movement; 1) the planning stage, 2) the organizing stage, 3 ) the implementation phase, 4) the supervision and evaluation stage, and 5) follow-up stage. Some of the steps carried out are aimed at shaping the character of student leadership through the exemplary form, discipline, commendable morality, creating a conducive atmosphere, integration, and internalization of the formation and formation of students' noble morals according to Islamic teachings.nterviews with the school leadership, mentor HW, class teachers, students in grades 1 and 2, as well as student guardians at Lab school UMSIDA Muhammadiyah 1 Elementary School.
The application of child-friendly schools to shape the character of student leadership through the HW movement at Lab school UMSIDA's Muhammadiyah 1 elementary school for approximately two years shows a significant increase. The HW movement has different values and uniqueness has been applied in other schools. The amount and uniqueness of the kepanduan HW movement can be seen in its implementation in schools that go through several stages, including.

\section{A. Planning Stage}

The planning phase involves meetings of school leaders, teachers, HW trainers, school committees, and parents of students. As outlined in; (a) Articles of Association (AD) and By-Laws (ART), (b) HW Organization's Basic Guidelines, (c) HW Activities parent program, (d) HW Guidelines Guidelines. These four things determine the direction, development, and implementation of the HW movement including (a) the practice of the Islamic faith, (b) the formation of behavior according to Islamic teachings, (c) the Code of Honor Code, and (d) learning according to the rights and needs of students. Through the four basic principles of the HW movement in SD Muhammadiyah 1 Lab school, Umsida educates students to continue to develop and struggle to uphold the Islamic community.

\section{B. Organizing Stage}

At this organizing stage, the organizational structure of the HW is made in stages which have the main tasks and functions. In the HW scouting movement, students are not only given education related to physical and mental strengthening but also include the cultivation of virtue and noble character. The HW movement teaches its members to do righteous deeds with Islamic guidance. HW motto "Talk a Little Much Work" and "Fastabiqul Khairat."

C. Implementation Stage

The HW Movement, educators, and HW trainers provide learning from students' leadership experiences. The lead characteristics of the HW movement influences students' attitudes, behavior, and knowledge. The results of data analysis show the total character values that appear in three competencies, namely: (a) scientific approach, (b) cognitive, (c) skills. Leadership character indicators include: (1) self-confidence, (2) conveying ideas and thoughts, (3) being open to other people's ideas and opinions, (4) respecting friends and team, (5) fast and responsive, and (6)) disciplined and responsible 


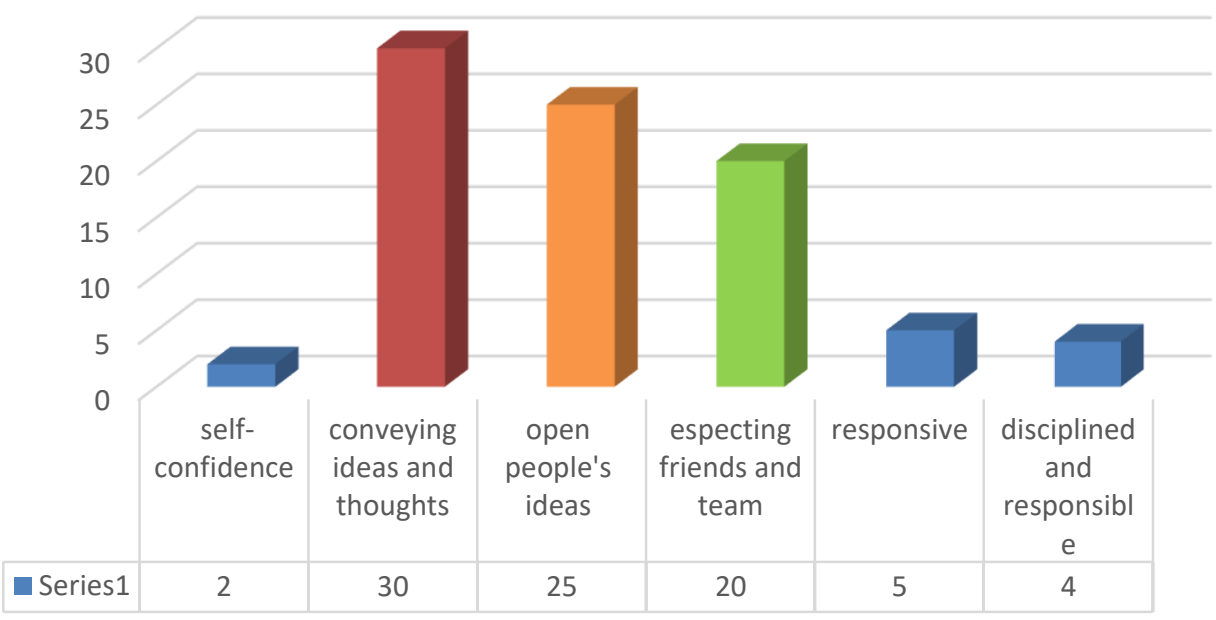

Fig.1. The First HW Leadership Characters

The results of leadership character assessment of students in grade $1 \mathrm{a}$ and $1 \mathrm{~b}$ at Lab school UMSIDA's Muhammadiyah 1 elementary school, three observations showed that at the first HW meeting whose leadership characters were at level 2.4 (poor), students less able to adapt and interact well in their new environment with friends and coaches of HW. Students do not yet have confidence in their abilities. Students do not have disciplined and responsible. Based on the results of the analysis at the first meeting, researchers together with school leaders, teachers, and HW trainers reflected on various obstacles to solving problems at the next $\mathrm{HW}$ meeting.

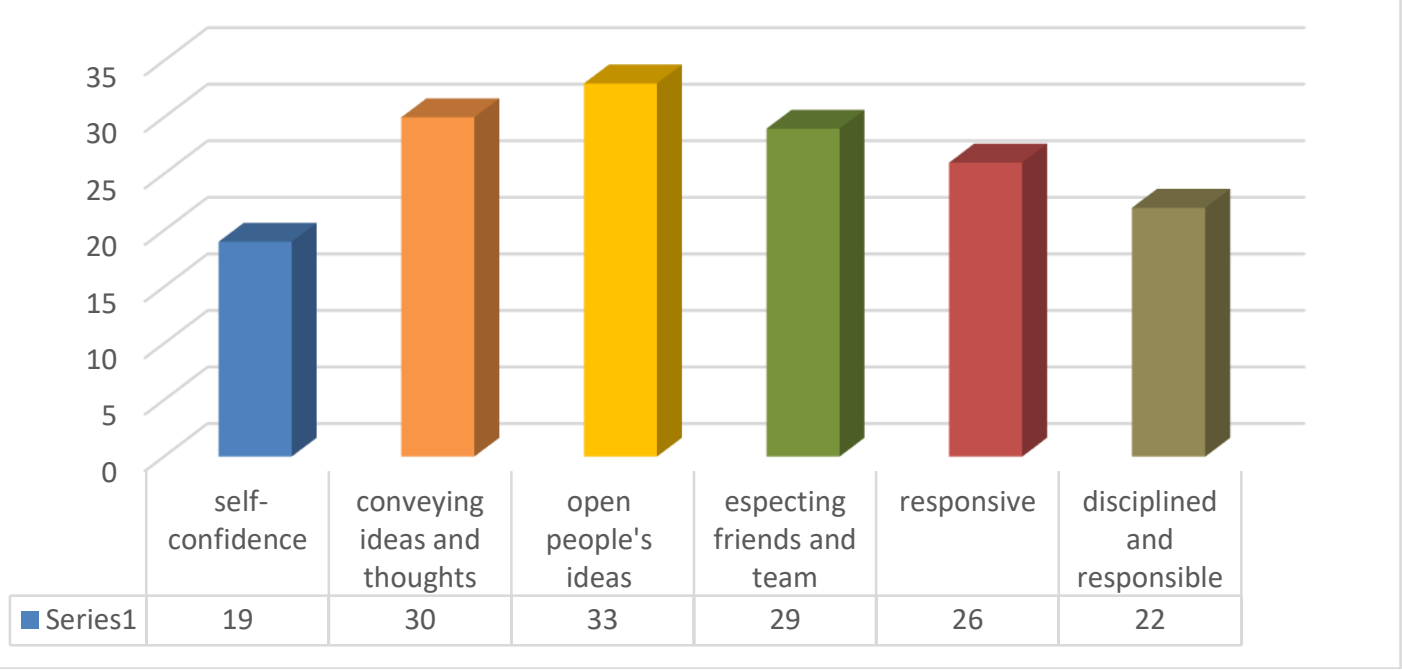

Fig. 2. The Second HW Leadership Characters

The second HW meeting showed an improvement in the lead character of most students at levels $2.6-2.8$ (moderate) with two people at level 3.0 (excellent). At this second meeting, students begin to look brave to interact with friends and teachers and begin to be able to adapt to the surrounding environment and the schedule of activities that have been programmed by the school. At the time of the builder, HW told the example of Rasulullah, who has empathy and compassion for all creatures created by Allah. At the 2nd meeting of the HW, there were 2 (two) students, namely Rasya and Najwa, who were seen pointing their fingers and told him that at home, he had a cat that was well-cared for and fed every day. Rasya said that every afternoon the father invited him to care for and give the newly hatched chicks. The other students seemed calm listening and did not dare to show themselves more active. 
Learning methods are interesting, not rigid and provide opportunities for students to explore their abilities to be able to improve and provide an attraction for their students to learn [2]. Therefore teachers, coaches, and parents must understand the characteristics of children in learning.

The HW activities students are invited to the reading room to enjoy reading and writing. Students at the HW activity color pictures of living things created by God. Students next mention the uses and benefits of living things that God created for human life on earth. There are four groups in the HW, where each group consists of 5-6 students, and during the learning activities, look enthusiastic working both individually and in groups in teams. [37]. Students are very enthusiastic about learning by using picture media. The pictorial story media is useful in teaching value education to elementary school students [38]. Learning environment affects their patience, calmness, and confidence when students bring a positive impact on improving student learning skills. [39]. Teaching the millennials era must be broad, flexible, and monitoring progress through provide the stimulus of learning and searching for complete skills. [40].

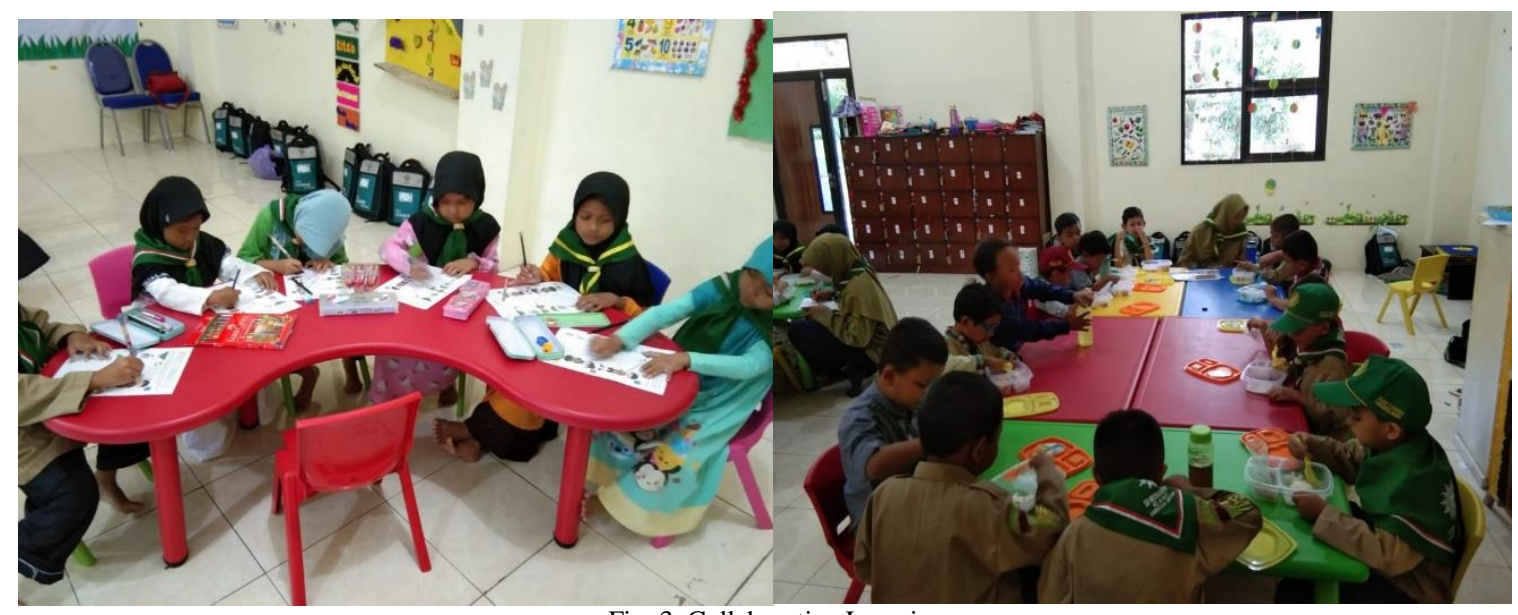

Fig. 3. Collaborative Learning

From the results of observations, the students seemed to be able to follow and understand well the instructions given by the coach of HW. Students can collaborate in doing assignments, want to teach their friends who do not understand, and are willing to lend their writing tools to friends who need them. The educational value of this HW activity is that students take wisdom by implementing the loyal behavior of friends, like helping and meritorious, and have a loving attitude for all creatures created by God. During lunch, students eat food that brings from their homes. One student named Haikal led his friends to pray before eating. When eating together, the coach of HW teaches students to share food with their friends. This joint eating activity teaches students to live tolerantly, love each other, and to live frugally and carefully. The educational value of this HW scouting activity is that students have a loyal attitude of friends, helpful, compassionate, and lifesaving and careful. 


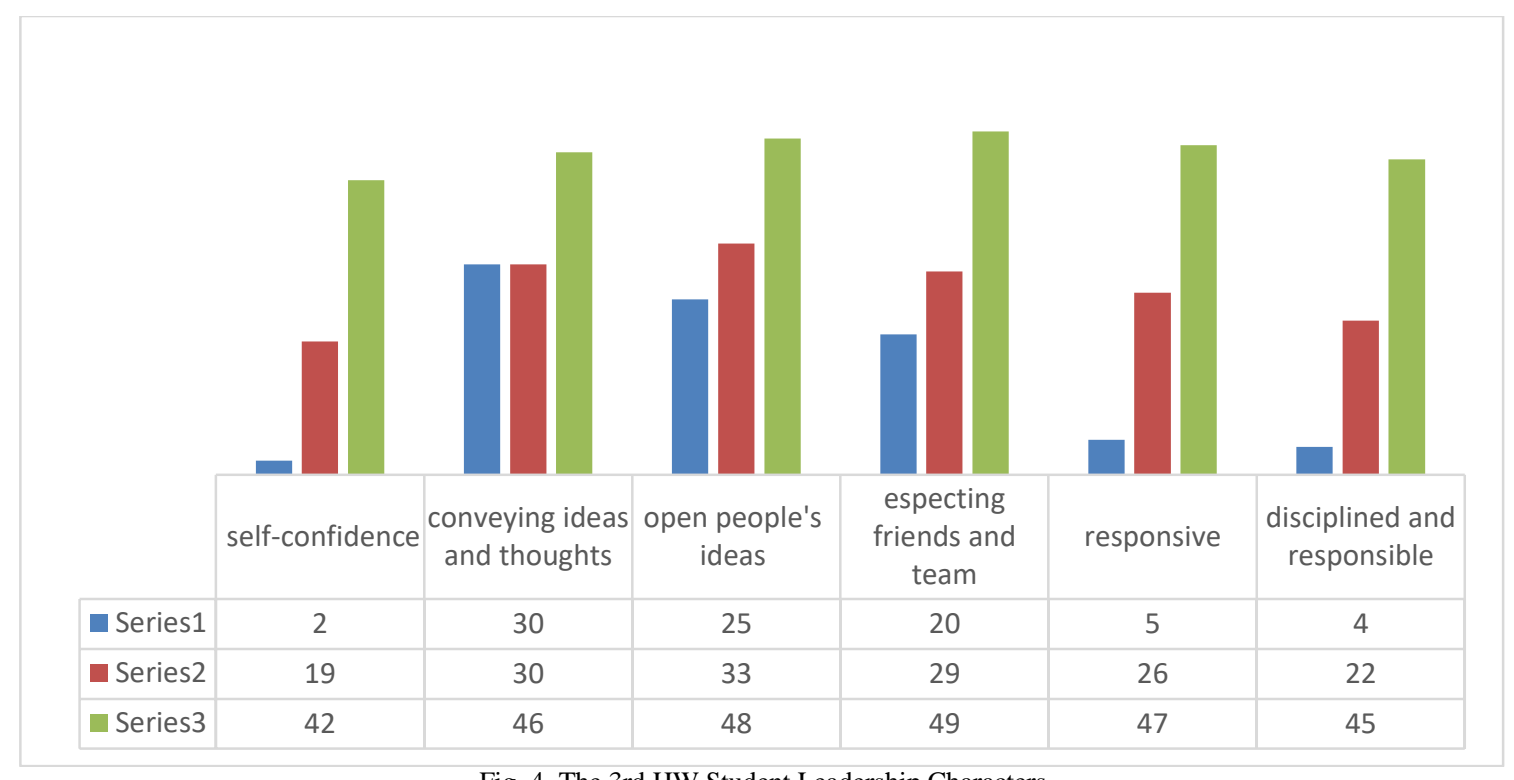

Fig. 4. The 3rd HW Student Leadership Characters

At the 3rd HW meeting, most students were at the level of leadership character 3.0 (right), some students were at the level of moderate leadership character, and no students had bad leadership character. At the 3rd HW meeting, students seemed to have responsibilities when given assignments by the teacher and the coach of the HW. When taking ablution, students appear orderly and do not fight over water. Students perform their rituals correctly and in an orderly manner according to the Islamic sharia taught, then complete the Sunnah Duha prayer in the congregation led by a teacher as the Imam of the prayer. During the congregational prayers, the students seemed to be orderly and solemn in worship. The HW at Lab school UMSIDA's Muhammadiyah 1 elementary school aims to be able to build student leadership character in collaborative inquiry, embedded, and directed by teachers, leading to responsive leadership and meaningful learning experiences

\section{Controlling and Evaluation Stage}

At the control and evaluation stage, the headmaster and teacher monitor the monitoring of the HW advisory team in carrying out $\mathrm{HW}$ activities for grade $1 \mathrm{a}$ and $1 \mathrm{~b}$ students at Lab school UMSIDA's Muhammadiyah 1 Elementary School. Some problems that occur related to HW include: a) prayer in congregation students need supervision, b) the packaging of HW teaching media that suits student needs, c) the rigid HW teaching system.

\section{Follow-Up Stage}

In the follow-up phase, the HW trainer is assisted by the teacher to revise some of the deficiencies based on the advice and input that has been obtained, including a) instilling the value of student awareness and responsibility on the importance of praying in an orderly and timely manner, b) HW scouting activities taught by the play method use a variety of educational media that are educational and fun, c) teaching systems that are not monotonous are only applied in the classroom but are more mobile learning, for example, by using the school library room, students sit in a circle (halaqa) in a park or school yard that is flexible, conducive, and packaged in a fun way.

\section{CONCLUSION}

The results of the above study show the importance of character building education early to students in schools in ways that are appropriate and fulfill the child's right to get a quality education. For this reason, teachers, principals, parents, and the community need to collaborate in implementing child-friendly schools that are integrated with Islamic values to motivate student learning and change their way of thinking and learning attitudes which tend to be rigid and monotonous [26]. The child-friendly school creating environment learning communities by learning calmly, adequately, comfortably, and safely from all disorders that can disrupt conduciveness education at school. Child-friendly schools must guarantee independence, no intimidation, violence, and threats from any party.

The leadership character building through the HW scouting movement is in line with previous research that leadership character through extracurricular activities held by schools with students having complex competencies on social, academic, and psychological dimensions. Entering the 21 st-century millennial generation is required to have cognitive, affective, and psychomotor abilities that are ready to face the challenges and changing times. For this reason, learning settings must be appropriate and able to grow skills towards the 21 st-century [41] 
The HW at Lab school UMSIDA's Muhammadiyah 1 elementary school aims to be able to build student leadership character. The character of leadership refers to Western and Asian leadership theories, which is based on cultural and practical knowledge in context suitability. The characteristics of Western and Asian leadership are then integrated into Islamic values in line with guidelines in realizing child-friendly schools to teach values, rules, norms in their lives [30]. This supports of research that learning engagement in collaborative inquiry, embedded, and directed by teachers, leading to responsive leadership and meaningful learning experiences [42]. For this reason, the creation of a child-friendly learning environment through the HW scouting movement requires teachers who are ready to: 1) train students' self-control, 2) create a collaborative learning atmosphere, 3) respect all student ideas and ideas, 4) involve and provide support to all students during learning, and 5) the teacher can be a listener and facilitator in learning [19].

The child-friendly school provides for children's participation in society of community, encouraging to develop children. As in article 4 of Law No.23 / 2002 concerning Protection Children that. The main principle in child-friendly schools is a provision, protection, and participation of the child, protecting and giving freedom in arguing, ask questions. The child-friendly cannot separate from application standards for child-friendly. The childfriendly must be made friendly educators achieve childfriendly patterns in totality.

The results of this study contribute to building character education from an early age for students into extracurricular activities such as Karate, Tapak Suci, Student Leadership Training (LKS), School Health Efforts (UKS), Flag raisers (Paskibra), and Scientific Mastery and Academic Ability Activities. This extracurricular activity refers to the concept of a child-friendly school that follows the rights and needs of students.

\section{ACKNOWLEDGMENT}

The author gives high appreciation to the Universitas Muhammadiyah Sidoarjo as the working author agency and the Muhammadiyah Diktilitbang Assembly who funded and facilitated this research activity, as well as the principal, class teachers, HW coaches and grade 1 students at Lab school UMSIDA's Muhammadiyah 1 elementary school

\section{REFERENCES}

[1] D. Baehaqi, "Optimalisasi Gerakan Kepanduan Hizbul Wathan untuk Pembinaan Karakter Warga Negara Muda," Pros. Semin. Nas. Pengemb. Pendidik. Karakter Bangsa Berbas. Kearifan Lokal, hal. 1-15, 2011.

[2] C. Kristjansson, K; Walker, David; Jones, Character Education in UK Schools, no. February. University of Birmingham, 2015.

[3] E. Crawford dan N. W. Arnold, “' We don' t Talk about Undocumented Status ... We Talk about Helping Children ': How School Leaders Shape School Climate for Undocumented
Immigrants," Int. J. Educ. Leadersh. Manag., vol. 5, no. 2, hal. 116-147, 2017.

[4] C. Mombourquette, "The Role of Vision in Effective School Leadership," Int. Stud. Educ. Adm., vol. 45, no. 1, hal. 23, 2017.

[5] C. Sunaengsih, M. Anggarani, M. Amalia, S. Nurfatmala, dan S. D. Naelin, "Principal Leadership in the Implementation of Effective School Management," Mimb. Sekol. Dasar, vol. 6, no. 1, hal. 79-91, 2019

[6] P. A. P. Buhere, "Influence Of Headteachers' Transformational Leadership Style On Implementation Of Inclusive Education In Public Primary Schools In Uasin Gishu County, Kenya," Int. J. Educ. Res., vol. 7, no. 4, hal. 15-28, 2019.

[7] A. Rehman, M. Khan, dan Z. Waheed, "School Heads' Perceptions About Their Leadership Styles," J. Educ. Educ. Dev., vol. 6 , no. 1, hal. 138-153, 2019.

[8] J. L. Smikle, "Connecting Values to Leader and Leadership Development Connecting Values to Leader and," J. ValuesBased Leadersh., vol. 12, no. 1, hal. 1-8, 2019.

[9] N. Rinfre dan J. Grenier, "Leadership Development: Three programs that maximize learning over time," J. Leadersh. Educ., no. April, 2019.

[10] Australian Children's Education and Care Quality Authority, The Educational Leader Resource. Sydney New 2000, 2019.

[11] V. Cruickshank, "The Influence of School Leadership on Student Outcomes," Open J. Soc. Sci., vol. 05, no. 09, hal. 115-123, 2017.

[12] J. P. Hester, "Values-Based Leadership in a Time of Values Confusion Values-," J. Values Based Leadesh., vol. 12, no. 1, hal. $1-11,2019$.

[13] Musrifah, "Pendidikan Karakter dalam Perspektif Islam," Edukasia Islam., vol. 1, no. 1, hal. 119-133, 2016.

[14] P. Aynur, "The Need for Character Education," Int. J. Soc. Sci. Humanit. Stud., vol. 3, no. 2, hal. 23-32, 2011.

[15] A. Lumpkin dan R. M. Achen, "Leadership Education: Assessment of Learning in A Sport Leadership Course," $J$. Leadersh. Educ., no. April, 2019.

[16] R. Khoury, "Character Education as a Bridge from Elementary to Middle School: A Case Study of Effective Practices and Processes.," Int. J. Teach. Leadersh., vol. 8, no. 2, hal. 49-67, 2017.

[17] S. et al Wright, Hannah; Williams, "Designing for urban childhoods," 2017.

[18] M. J. Susilo, "Leadership Model in Muhammadiyah to Create Independence School," Proceeding Int. Symp. Transit. From Sch. to Work, no. February, hal. 125-131, 2017.

[19] S. Maoto, "Creating a child friendly psychosocial learning environment in mathematics: A case of problem solving in grade 6," Mediterr. J. Soc. Sci., vol. 5, no. 23, hal. 1048-1055, 2014.

[20] H. J. M. Pennings, M. Brekelmans, P. Sadler, L. C. A. Claessens, A. C. van der Want, dan J. van Tartwijk, "Interpersonal adaptation in teacher-student interaction," Learn. Instr., vol. 55, hal. 41-57, 2018.

[21] K. Zendah, "Exploring School-Based Stakeholder Support for Teachers in the Promotion of Child-Friendly School Environments Abstract :," Int. J. Innov. Res. Dev., vol. 7, no. 6, hal. $162-171,2018$.

[22] F. Wadjdy, "Education in Border Regions," TARBIYA J. Educ. Muslim Soc., vol. 4, no. 2, hal. 224-231, 2017.

[23] UNICEF, “UNICEF Annual Report 2012 for Bhutan," hal. 1-33, 2014.

[24] F. Çobanoğlu, Z. Ayvaz-Tuncel, dan A. Ordu, "Child-friendly schools: An assessment of secondary schools," Univers. J. Educ. Res., vol. 6, no. 3, hal. 466-477, 2018.

[25] A. Hermino dan V. Luangsithideth, "Community Awarenes and Child-Friendly School at the District Nonghet, Northern of Lao PDR,” Asian Soc. Sci., vol. 13, no. 11, hal. 109, 2017.

[26] N. Purwati, S. Zubaidah, A. D. Corebima, dan S. Mahanal, "Increasing Islamic Junior High School students learning 
outcomes through integration of science learning and Islamic values," Int. J. Instr., vol. 11, no. 4, hal. 841-854, 2018.

[27] P. Kusumandari dan N. Rohmah, "Manajemen Ekstrakurikuler Hizbul Wathan untuk Membentuk Karakter Kepemimpinan Siswa Kelas X SMA Muhammadiyah 2 Yogyakarta,” vol. 3, no. 1, hal. 267-278, 2018.

[28] A. Schleicher, Preparing Teachers and Developing School Leaders for the 21st Century: Lessons from around the World. OECD Publishing, 2012.

[29] L. Mandiudza, "Child Friendly Schools," Greener J. Educ. Res., vol. 3, no. 6, hal. 283-288, 2013

[30] S. Salmi dan K. Kumpulainen, "Children's experiencing of their transition from preschool to first grade: A visual narrative study," Learn. Cult. Soc. Interact., vol. 20, no. October 2017, hal. 58-67, 2019.

[31] M. A. Khalifa, M. A. Gooden, dan J. E. Davis, "Culturally Responsive School Leadership: A Synthesis of the Literature," Rev. Educ. Res., vol. 86, no. 4, hal. 1272-1311, 2016.

[32] M. Leino, "The child friendly school: an idea versus reality," Probl. Educ. 21st century, vol. 29, hal. 82-88, 2011.

[33] N. W. Yasina, Maizura; Abdullah, Sur Surayyah M; Roslan, S; Wahat, "Motives For Moral Behavior Among Malay Muslim Student Secondary School," TARBIYA J. Educ. Muslim Soc., vol. 5, no. 1, hal. 43-56, 2018.

[34] L. Abu, M. Mokhtar, Z. Hassan, dan S. Z. Darmanita Suhan, "How to Develop Character Education of Madrassa Students in Indonesia," J. Educ. Learn., vol. 9, no. 1, hal. 79, 2015.

[35] A. Y. Nuryantini, Karman, dan A. Holik, "Integration Science and Religion in Physic Subject: An Analysis In Islamic Higher
Education," TARBIYA J. Educ. Muslim Soc., vol. 1, no. 5, hal. 11-18, 2018.

[36] M. Patton, Qualitative research and evaluation methods. Thousand Oaks: CA: Sage, 2015.

[37] E. F. Fahyuni, "How the teacher' s teaching is ? the guidedinquiry-worksheets to enhance science process skills," J. Phys. Conf. Ser. Pap., hal. 0-5, 2019.

[38] E. Fariyatul dan A. Bandono, "The use of value clarification technique-based- picture story media as an alternative media to value education in primary school," Harmon. J. Arts Res. Educ., vol. 17 , no. 1 , hal. $68,2017$.

[39] J. J. Turner, P. S. Amirnuddin, dan H. S. I. Singh, "University legal learning spaces effectiveness in developing employability skills of future law graduates," Malaysian J. Learn. Instr., vol. 16, no. 1, hal. 49-79, 2019.

[40] C. A. Vaithilingam, R. A. Gamboa, dan S. C. Lim, "Empowered pedagogy: Catching up with the future," Malaysian J. Learn. Instr., vol. 16, no. 1, hal. 1-22, 2019.

[41] I. N. Bagiarta, I. W. Karyasa, dan I. N. Suardana, "Komparasi Literasi Sains Antara Siswa Yang Dibelajarkan Dengan Model Pembelajaran Kooperatif Tipe GI (Group Investigation) Dan Model Pembelajaran Inkuiri Terbimbing ( Guided Inquiry ) Ditinjau Dari Motivasi Berprestasi Siswa SMP," vol. 5, no. 4, hal. $1-11,2015$

[42] S. Cherkowski dan L. Schnellert, "Exploring Teacher Leadership in a Rural, Secondary School: Reciprocal Learning Teams as a Catalyst for Emergent Leadership.," Int. J. Teach. Leadersh., vol. 8, no. 1, hal. 6-25, 2017. 